\title{
Responding to the challenge of Black Theology: Liberating Ministry to the White Community - 1988-1990
}

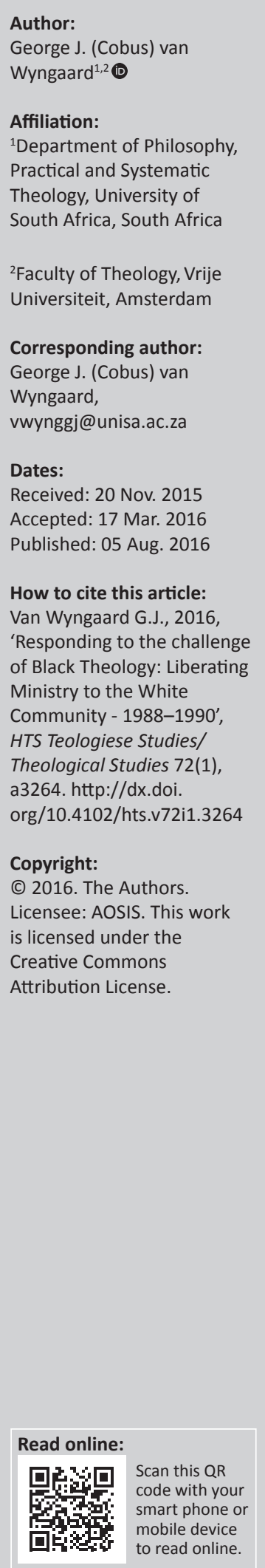

This article provides an initial overview of the Institute for Contextual Theology's 1988-1990 project on A Liberating Ministry to the White Community, particularly exploring the main themes that emerged from national workshops during the 3 years. The project participants set out to think through the questions of a ministry to the white community in dialogue and in solidarity with Black Consciousness and Black Theology and the article seeks to explore the extent to which this initial focus was attended to in the main themes developed. Particular attention is given to how the project developed the notion of the white church as a 'site of struggle' and the accompanying social analysis and understanding of the role of prophetic theology.

\section{Introduction}

In 1987, the Institute for Contextual Theology (ICT) ${ }^{1}$ embarked on a programme of thinking through the implication of a conscious ministry to the white community within the context of white racism and apartheid. Called A Liberating Ministry to the White Community (LMWC), the project ended in 1990 and has been all but forgotten. Gerald West, a central committee member in the project, recently pointed out that, according to his knowledge, nothing has been published on this project and he recommended that a fuller account of the project should be undertaken (West 2012:70). This article is a first attempt at giving an account of this project and, in particular, analysing the ecclesial and social analysis underpinning it.

Beyond the mere historic value of shedding light on an aspect of the struggle against apartheid that has received inadequate or almost no attention, this project also marks one of the few examples of white Christians consciously attempting to think through the implications of Black Consciousness and Black Theology. It is even more important that a group of people, rather than an individual white theologican, attempted to think through grassroots programmes. Recently Klippies Kritzinger, another central committee member of the project, referred to this project as an example of the possible kind of work needed in contemporary South Africa: 'a process of iterative withdrawal and reconnection on the basis of all the fault lines that separate us' (Kritzinger 2015). ${ }^{2}$ Against the background of contemporary debates on how white South Africans can participate in anti-racist work, the project discussed below represents an important earlier attempt by white South Africans to reflect from within the Christian churches on which challenges white people need to work on within a racist society.

After an overview of the project, I start by introducing a debate between Albert Nolan's God in South Africa (1988) and Kritzinger's PhD thesis Black Theology: A Challenge to Mission (1988). These individuals played a key role in the project, published these works around the time the project started, and represent different analyses of the struggle and responses to Black Theology. Aspects of the debate also became visible in early references to Black Theology and later attempts at relating race and class together in the social analysis done.

In the longest section of the article, I explore key aspects of the theological and social analysis found within LMWC. This is mainly focused on 'the white church as a site of struggle', which was the theme for two of the three annual workshops. The documents that contribute to this analysis are part of the collection of unpublished material, minutes, and handwritten notes on the project 1.The ICT was a nondenominational organization established in 1981 with the conscious aim of developing a contextual theology that
could challenge apartheid. It played a key role in the publication of the 1985 Kairos Document (Kritzinger 2004:92).

2.This process refers to a practice in which people work in groups along and across the fault lines. For example, in work on gender, men and women would need to work separately but also collectively, in an iterative process that allows them to address questions of gender identity and relations of power.

Note: Earlier versions of this article was presented at the 2015 meeting of the Transatlantic Roundtable on Religion and Race and Note: Earlier versions of this article was presented at the 2015 meeting of the Transatlantic Roundtable on Religion and Race and
submitted for the Centre of Public Theology at the University of Pretoria symposium 'Black Theology of Liberation Twenty One Years Later'. 
kindly made available by Klippies Kritzinger, Fiona Bulman, and Gerald West. ${ }^{3}$

\section{Overview of A Liberating Ministry to the White Community}

The ICT AGM passed the following motion in 1987:

[that] the ICT takes up the matter of a positive ministry to the oppressor with particular attention paid to issues such as guilt, fear and material interests in the white community. (Institute for Contextual Theology 1988a)

Alex Bhiman was acting general secretary at the time and called the first meeting on 15 September 1987. It was attended by Willem Saayman, Denise Ackerman, Beyers Naudé, Nico Smith, Michael Worsnip, Nico Horn, Alex Bhiman, and Klippies Kritzinger (Institute for Contextual Theology 1987:1). Two key points from this meeting, which emerged repeatedly during the project, are that work on a LMWC must be done next to and in dialogue with Black Theology and black theologians and that the project should focus on the grassroots and not be overly academic (Institute for Contextual Theology 1987:2). At this meeting, Kritzinger was elected convener for the first one-day meeting planned for about 50 people at which the project was to be explored further.

After further meetings of a smaller group (Kritzinger, Naudé, Worsnip, and Bhiman) Kritzinger produced a draft position paper. ${ }^{4}$ The position paper placed a strong emphasis on the relationship between white liberation and Black Theology. Since this overt commitment is key to my evaluation ${ }^{5}$ of the project I quote it in full:

There can be no sense in which the undertaking of such a ministry to whites can be divorced from the insights and directions of Black and liberation theology. In fact, the whole exercise is stimulated and called forth by Black Theology, and proceeds by constant interaction with black theologians. It is thus not an exclusively white enterprise, but a joint effort of black and white Christians to develop a liberating ministry to white people. Since we recognise that oppressors are incapable of bringing about liberation, we affirm that the oppressed need take the initiative and critically accompany this enterprise. (Institute for Contextual Theology 1988a)

From 1988 until 1990, a yearly national conference was held. The intention was that the national conference would be repeated regionally, and that regional conferences would result in local working groups which in return would result in the development of the national working group (Bulman 1989).

3.This work would not have been possible without their generosity of spirit and time, both in making personal archives available and also sharing their memories of this project.

4.Correspondence indicates that at least Michael Worsnip also contributed to the position paper. In a letter on 29 January 1988, Rev. J.M. Lamola, ICT projects coordinator, thanks Kritzinger for the position paper and then also writes that "I am impressed at the way Michael has been able to intergrate (sic) the longterm (revolutionary ... shh) objectives of this without exposing the project as such to being seen as another mere radical stunt' (Lamola 1988). In this letter, Lamola also recommends that the name of the project be changed from A Liberating Ministry to Whites to $A$ Liberating Ministry to the White Community.

5.The choice to focus my evaluation through the lens of this commitment was motivated, on the one hand, by the contemporary focus on Black Theology in South Africa, tied to the growing emphasis on the importance of Black Consciousness today and, on the other hand, by the conferences at which this research was initially presented, where the focus was explicitly on race and Black Theology.
Papers would be commissioned on specific themes and then made available to be presented regionally. Although the papers almost never indicate authorship, probably because they are presented as the work of the group, authorship can be gathered from minutes of meetings and other correspondence. I indicate individual authorship only if it is clear that a single author wrote a paper or letter.

Meetings were held in September 1988, June 1989 and July 1990.

The 1988 meeting focused on introductions to the white community through a demographic overview indicating white South Africans' stance on various aspects of apartheid, members of the central committee presenting thoughts on possibilities for transformation among Afrikaners in particular, and presentations by extra-parliamentary groups working to garner support for the democratic movement among white South Africans. The central committee evaluation of the 1988 workshop reveals quite a bit of discomfort around the approaches of groups working within the white community that are not able to confront white complicity and call for white repentance, or that in their view did not adequately address the depth of the problem (Institute for Contextual Theology 1988e:2).

The June 1989 meeting was, in many ways, dominated by the inputs of Albert Nolan and Chris Langeveldt on 'skills for doing theology, social analysis and planning' and 'the church as a site of struggle', respectively. These also became the central part of the regional meetings, where these were held. Nolan and Langeveldt were both Catholic priests, part of a small group called together by Frank Chikane, then director of the ICT ${ }^{6}$, after the bombing in Botswana in 19857, in order to start mapping a theological response to the situation, and both closely involved with the writing of The Kairos document (Mabuza 2009:88). Their introductory papers are discussed in detail below, since these had a substantive influence on the process.

In February 1990, F. W. de Klerk announced the unbanning of the liberation movements, and the Rustenburg consultation was held in November 1990. Consequently, 1990 represents a certain historic marker within both the history of South Africa and the church struggle against apartheid (Vosloo 2013:16). The LMWC had their annual meeting in July 1990. The focus of the meeting was very similar to the 1989 conference, taking the same title and focus area as 1989 and not admitting new participants who had not been present in 1989 (Kritzinger c 1989). The emphasis was on deepening the skills and thoughts introduced in 1989.

Denise Ackerman was a member at the beginning of the project, but withdrew early on in order to complete

6.Although Chikane was director of the ICT from 1983-1987, he was detained

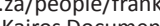
chikane). He initiated conversations that lead to the writing of The Kairos Document
after he was released from jail in 1985 (Mabuza 2009:89-90)

7.On 14 June 1985, the South African Defense Force crossed the border to Botswana in a raid on Gaborone. The target was MK officers but the raid also resulted in the death of a six-year-old boy and other civilians. 
her dissertation. In a letter after the first meeting, however, she describes the original purpose of this project as having a far more (academic) theological aim: to first develop a white liberation theology, which would then be translated into a liberating ministry for whites (Ackerman 1988:1). Handwritten notes by Kritzinger from (probably) 1987 also emphasise an academic dialogue along similar lines, with seminars following the pattern of iterative withdrawal and reconnecting between black and white theologians proposed and publications being planned. The position paper, however, emphasised that the project would not be an 'abstract theological exercise' but should influence as many people as possible (Institute for Contextual Theology 1988a:2). In the report of the first gathering, the focus of the project was already described as an exploration of strategies (Institute for Contextual Theology 1988b:2). Nevertheless, the argument below is an attempt to provide an overview and analysis of exactly this more abstract and conceptual work on liberating whiteness found within the project.

\section{Nolan and Kritzinger in response to Black Theology}

Nolan published God in South Africa in 1988, the same year Kritzinger completed his doctorate titled Black Theology-A Challenge to Mission. Both played key roles in LMWC, and given the timeline for LMWC, 1988-1990, and the focus of their respective works, these are important markers illustrating the theological voices that formed the community of people who engaged in the LMWC workshops. In this section, I briefly introduce a debate on the relevance and role of Black Theology in their respective works, which has particular relevance in light of the aforementioned commitment in the position paper.

In their introductions, they evaluate the relevance and importance of Black Theology in different ways. In highlighting their different evaluations, some of the ideological and theological differences within LMWC (as well as other anti-apartheid groups) become more visible.

Nolan (2004) writes:

Today Black Theology is faced with the dilemma of what is called the ideological split between Black Consciousness and the nonracialism that is associated with the Freedom Charter. Black Theology has been a theological reflection upon the meaning of Black Consciousness. If the majority of the people have now adopted the non-racialism of the Freedom Charter, what does this mean for Black Theology? It seems to me that what matters is not what name we give to our theology, but that it remains a genuine theological reflection upon what God is doing in our country today. (p. 4)

While West (West 2014:360) indicates that Nolan's work was primarily a contextualisation of Latin American liberation theology in South Africa, Kritzinger consciously took a different route. In introducing his thesis, he writes:

My second basic conviction ... is that a liberating theology for South Africa should draw its primary inspiration and methodology from its own context, not from Latin America or elsewhere. (Kritzinger 1988:1)
But more importantly, Kritzinger explicitly differs from Nolan's rhetorical question (which Kritzinger read as implicitly questioning the relevance of Black Theology in the late 1980s) and its implication that the theological relevance of Black Theology is connected to majority support within the black community (Kritzinger 1988:4). But most important for understanding the positions on the table in LMWC, Kritzinger argues that it remains relevant for white theologians to listen and respond to Black Theology primarily because they 'have not yet responded adequately to Black Theology (in any of its phases)' (Kritzinger 1988:5).

Gerald West's post-apartheid overview of liberation theologies in South Africa highlights this particular tension as well. West lists a number of liberation theologies, but gives particular attention to the ICT's contextual theology and Black Theology. ${ }^{8}$ West highlights as one of the main shortcomings of The Kairos Document, in which Nolan played a key role, its lack of explicit engagement with South African Black Theology (West 2014:361). Beyond the lack of explicit engagement, the downplay of the racial dimension in analysis of the South African problem by The Kairos Document was critiqued early on from a Black Theology perspective by Mokgethi Mothlabi ${ }^{9}$, even while acknowledging that Black Theology can identify with the prophetic theology The Kairos Document (Mothlabi 1987:93, 100). Kritzinger, in following Mothlabi's critique, described this downplay of race as a strategic move, in that its emphasis on class provided a form of liberation theology that could more easily be endorsed by both black and white theologians, breaking the separation between the two groups in the struggle against apartheid (Kritzinger 1988:79).

These different voices also become important in understanding the LMWC project. In spite of an initial emphasis on Black Consciousness, which would call on centring race in the analysis, the project focus was in many ways moved towards class, perhaps for similar strategic reasons as those pointed out in Kritzinger's response to The Kairos Document. The point, then, is not how we name theologies (to echo Nolan), but rather how LMWC dealt with the relationship between race and class, a debate that continues into the present.

\section{The white church through the eyes of A Liberating Ministry to the White Community}

The preceding is an overview of the 3 years of LMWC and some markers of the different interpretations of the importance of consciously drawing from Black Theology and Black Consciousness in thinking through and putting in

8.The third very important stream in West's analysis is African Women's Theology, which has little bearing on the project under discussion except that, as will be indicated, gender remained a largely unresolved issue within the project, and the intersection between gender and race was far from the focus of the agenda of this project.

9.Kritzinger followed Mothlabi's critique (Kritzinger 1988:79). Both are, however, signatories and both, in the words of Mothlabi, would approve of the general thrust (Mothlabi 1987:100) of the document. 
place a ministry to the white community. I now highlight aspects of the social and ecclesial analysis that informed the project and the ecclesiological reflections developed during this project. The section is almost exclusively descriptive and draws exclusively on the unpublished material from the project. It serves as a first attempt at breaking the silence on this project. I start with the title of the 1989 and 1990 national workshops, which highlight the main emphasis of the project.

\section{The Church as a site of struggle}

Perhaps no theme was more prominent throughout the project than the emphasis on the Church as a site of struggle. The theme emerged at the 1988 conference and Tom Waspe then requested an analysis along these lines (Institute for Contextual Theology 1988b:23). Chris Langeveldt was tasked to prepare a paper on this for the 1989 conference, and the paper was then repeated in simplified form at regional conferences (Bulman 1989:2). This also became the title of the 1989 and 1990 conferences, but the conference workshops focused particularly on the white church as a site of struggle. The social and theological analysis of the project is best understood when read from within this perspective.

While the language was commonly used, Langeveldt provided conceptual clarity on the notion 'site of struggle'. In particular, the focus of LMWC was on the 'white church as a site of struggle'. I first provide a more general description, and then more closely examine the implications of understanding the 'white church' under the late stages of apartheid the church as the 'site of struggle'. This is then explored further in the next two sub-sections.

Sites are the metaphoric 'places' where people are brought together through a common set of social practices. Social practices involve activities such as working, praying or studying, and sites are the places where a group of people are involved in these social practices. The school is then a site of education, the church a site of religion. At the same time social practices can contain certain contradictions within themselves. Contradictions, within and between sites, can occur when social practices become dysfunctional. Examples include the claim that apartheid produced harmony versus its actual effect was protest and disharmony. This became a contradiction between sites when conflict arose in which both the church and state contested issues of moral authority. The church preached, for example, that all people were created equal yet barred some (such as women) from leadership. Social change will only be possible when such contradictions exist (in brief, there is no need for social change if social practices do not exhibit certain contradictions), but also requires a consciousness of the contradictions. A consciousness of contradictions within or between sites of social practices leads to struggle of some sort, and only through struggle does social change occur. Raising consciousness of contradictions is therefore of utmost importance (Langeveldt 1989).
A broad distinction can be made between political, economic, and ideological sites (Langeveldt 1989:3) ${ }^{10}$, although there is much overlap. The church is, however, primarily a site of ideological struggle: 'The church deals with ideas, beliefs, culture, faith and prayer. Therefore the nature of the church as a site of struggle means that it will be a site of ideological struggle, that is to say a struggle over ideas, beliefs, culture, faith and prayer, or, as has often been said, it is a struggle about symbols of religion and their meaning' (Langeveldt 1989:6).

Langeveldt's key point is that the church as a site of social practices becomes a site of struggle because it is a site of contradictions. In his argument, the church will 'always' be a site of contradictions. The opposite of a site of struggle is that the church is a true community. But the church will only be a true community 'when it is in complete harmony with itself and the rest of society and until that far distant reality takes place, the church will be a site of struggle' (Langeveldt 1989:5). Stated differently, the church as true community is an eschatological notion. But, in this world, the church will always be troubled with contradictions, and when conscious of these contradictions, it will be a site of struggle. As such, the church is a site where the struggle is about ideas and symbols.

For the purpose of understanding the project, the key point is that one task of prophetic theology, and of Christians working with a prophetic imagination, is to participate in the struggle within this site. This implies highlighting contradictions, forming consciousness about contradictions and organising for change. ${ }^{11}$ But to understand the strategic thinking happening we need to understand how the white community and white church were described at this point.

While Black Theology is considered an intellectual and ideological call together with which the project seeks to explore white liberation, another aspect repeatedly mentioned as informing the project is a perceived change within the white community by the second half of the 1980s. The resolution passed by the ICT in 1987 is explained as informed by a growing interest among white South Africans in the democratic movement (Institute for Contextual Theology 1988c:2), a growing optimism that white opinion could be shifted away from support for the National Party (Institute for Contextual Theology 1988d:1), and growing support for future non-racialism (Institute for Contextual Theology 1988d:3).

\footnotetext{
10.Though no sources are indicated in the document, the emphasis of ideological sites correlates with a Gramscian emphasis on culture or civil society as important for the struggle of the left. In particular, the analysis of the church as a site of struggle correlates a reading common among the European left that stresses the distinction between state and civil society (compare Anderson 1976:26-31, 34).

11.Some confusion might have existed. Langeveldt clearly emphasises that the struggle is within the church, since the church reflects the same spread of ideas and forces as are found in society. Writing in 1991, but writing from his own notes and forces as are found in society. Writing in 1991, but writing from his own note and without access to the full text of Langeveldt's lecture, Willem Saayman gives brief overview of the church as a site of struggle. Saayman, however, repeatedly interprets this to mean that the church should become part of the struggle. Rather than Langeveldt's emphasis that the church is inevitably a site of struggle, Saayma uses this language to call for the church to 'become' a site of struggle, which in his argument implies becoming an ally in the struggle by playing a role in assisting people to find meaning (Saayman 1991:117-120).
} 
In describing the ideological struggle of which the church is a particular site, church and society in general, but the white church and society in particular, are described as representing a linear distribution of prophetic, middle-ground and conservative people.

Within LMWC, 'prophetic' is used in line with the prophetic theology of The Kairos Document, on which I say more in a moment, and 'conservative', as those seeking to actively defend the status quo (Institute for Contextual Theology 1989a:7-8). The middle ground is, however, more difficult to define, partly because different groups around this time used it in different ways.

For the project, the 'white middle-of-the-road people' it is concerned with are those who 'are open to changing ... a group that can be influenced' (Institute for Contextual Theology 1989b:3-4). The minutes of the first meeting reveal an analysis which states that white South Africans seeking to maintain the status quo are not a majority, but rather that the majority who are open to some form of a transformed society (not necessarily unconditional acceptance of the restructuring of society) is not drawn into a process of change, something which LMWC hoped to contribute to (Institute for Contextual Theology 1988b:7).

Drawing on this aspect of the project in a recent description of the Dutch Reformed Church in Africa and the Dutch Reformed Mission Church's struggle for justice in the period 1986-1990, Kritzinger described these three groups as follows:

In doing this, he consciously describes these groups through their theological commitments. While LMWC worked with the white church in mind, the theological lines are largely similar.

The influence that LMWC then hopes to have is to shift middle-ground white opinion towards full acceptance of the agenda of the democratic movement. This move is perhaps best described as moving white people from a position of sympathy to one of solidarity (Institute for Contextual Theology 1988b:2). However, there is also recognition that, along the way, there are numerous smaller shifts that white people make, which 'range from basic acceptance of integration to active participation in the processes of change' (Institute for Contextual Theology 1988b:17). For example, one key issue during the project was the clear signs that an era of negotiations would arrive and the fear that the nationalist government would attempt to rush and manipulate this process. Together with other organisations, the project attempted to contribute to concrete conversations

TABLE 1: Churches' position and involvement in terms of political realities.

\begin{tabular}{lll}
\hline Prophetic & Centre & Conservative \\
\hline Standing for justice & Being God's church & Preserving the status quo \\
(working for & (working for reconciliation) & (preventing transformation) \\
transformation) & & \\
\hline
\end{tabular}

Source: Kritzinger 2013:99 in white communities, including work to advocate that negotiations should only proceed after the terms of the democratic movements were accepted (Institute for Contextual Theology 1989b:3-4, 1989c).

The church is a site of struggle because these different positions visible in society are also visible within the church, among both ordained and lay members. The struggle is between competing beliefs, symbols, and meaning, struggle around which different parts of the church participate. The goal of prophetic theology is to oppose those seeking to preserve the status quo, those who support injustice, and to draw a deeper commitment to work to transform the society from those who are open to change.

\section{Social analysis}

Nolan (Nolan 1989) and Langeveldt (Langeveldt 1989) worked with the same social analysis of South African society. Society is made up of different classes of people and different social groups. As a capitalist society, South Africa is made up of a capitalist (Langeveldt) or ruling (Nolan) class, a middle class, and a working class. But people also belong to social groups, and race is one of these social groups.

In Nolan's analysis of society, we find a description that decentres race as a problem in South Africa in favour of class. Firstly, Nolan argues for analysis on different levels: psychological, social and structural. A social analysis reveals that tension exists between social groups, while a structural analysis reveals that the deeper problem is that of structural domination. For Nolan, the structural domination is class based, yet these classes largely corresponded with social groups under apartheid.

Secondly, in response to the analysis, Nolan indicates how different solutions are proposed depending on the lens through which an analysis is being made: a social analysis results in highlighting the reconciliation of black and white South Africans while a structural analysis results in highlighting the restructuring of society. Nolan maintains that reconciliation as a response to the problem in South Africa is based on an incorrect social analysis; it is an answer that assumes that the problem is the competition for power between two social groups. The project attempted to teach white Christians that the problem should be understood as a structural conflict of domination and oppression by some over others. The response should therefore be the restructuring of society more than the reconciliation of social groups (Nolan 1989:5-7).

The result of Nolan's analysis is that it risks a class reductionism, in which the problem of whiteness is reduced to its position within a capitalist system. This becomes explicit in statements such as the following:

Much of the behaviour of whites in our society has nothing to do with their whiteness as such but everything to do with their positions of power and wealth in the South African pyramid. Whites often say and do things simply because they are on top 
and in power. In other words if whites were in a different position in the hierarchy of power and privilege they would act and speak quite differently. (Nolan 1989:7)

This materialist analysis cannot engage with the notion that whiteness is also maintained through assumptions about intellectual and moral superiority that are not necessarily dismantled by an economic restructuring of society, important as such a restructuring is in the disruption of whiteness. Drawing on the language of the previous section, and noting a tension between these two documents, this social analysis seeks to articulate a response to the economic struggle but does not respond to the ideological struggle of whiteness in the church: the struggle around faith, beliefs, and symbols that reinforce whiteness as a social phenomenon.

\section{The task of prophetic theology in the white church}

Given that the church as a site of struggle was the preferred analysis of the conference workshops, noting the options rejected in the process helps to clarify some ecclesiological assumptions. I ignore the possible ways in which conservative and middle-ground forces would see the relation between church and struggle, since these were clearly not options for LMWC. But prophetic theology itself could see the relation between church and struggle, more particularly between prophetic church and struggle, in at least four ways.

Two of these call for the withdrawal of the prophetic voices from the church. This might imply a complete withdrawal into new worshipping communities separate from the 'unconverted church' (described as a confessing church model). Alternatively, the prophetic voices remain as rebels within the church but actively refuse to participate in activities considered wrong (a rebel model). A third model sees the task of the church as supporting the struggle. In this model, the struggle is happening elsewhere and the church brings its resources and capacity to the struggle.

The rebel option implies that prophetic theology refuses to participate in what are considered the sinful activities of the church, while the confessing church option would set up alternative worshipping communities separate from the unconverted church. Different from either, seeing the church as a site of struggle, implies that we recognise that the church reflects contradictions similar to those found in society. Moreover, though the church should support the struggle of the people, the task of prophetic theology is also to conduct the struggle within the church (Institute for Contextual Theology 1989a:8).

Following the argument through the last three points brings us to a key strategic understanding of prophetic theology. The 'prophetic' of prophetic theology should not be understood as a typically 'radical' or 'voice in the desert' notion. 'Prophetic' should rather be understood as being the 'voice of the people'. The people, in this case, were the black majority of South Africa, calling for democracy and a deep restructuring of society. The task of prophetic theology within the white church as a site of struggle was to work to convince those white South Africans who were open to change to give their support to the black majority. The work of LMWC might then best be described as attempt to move the white middle ground from sympathy to solidarity with the black majority.

\section{From the struggle against apartheid to the disruption of whiteness}

The second decade after the end of apartheid, and recent years in particular, has highlighted the importance of ongoing critical engagement with race in South Africa. Important for this paper is the growing emphasis on Black Consciousness, the re-emergence of South African Black Theology in recent years, and the growing critical study of whiteness.

A summary definition of whiteness by Melissa Steyn captures the various aspects of the analysis of struggle in the LMWC debate and in the analysis below:

What, then, is whiteness? I believe it is best understood as an ideologically supported social positionality that has accrued to people of European descent as a consequence of the economic and political advantage gained during and subsequent to European colonial expansion. (Steyn 2005:121)

Though this need not imply the impossibility of a whiteness not bound to racism ${ }^{12}$, the very construction of whiteness cannot be read apart from a history of racism and white supremacy. The brief definition above draws together the different struggles noted in the project (political, economic, and ideological) and implies their intersection.

In e-mail correspondence shortly before his death, Willem Saayman wrote about this particular project and mentioned that he thought that it would be a good idea 'to see where we were going when FW [de Klerk] interrupted us so rudely'. ${ }^{13}$ He never had the chance to expand on this interruption, but I want to chance a possible response.

In many ways, the discourse on whiteness within the LMWC project revolved around apartheid. Imagining what whiteness would become beyond universal suffrage and a Bill of Rights was not easy, apart from the suspicion that class inequalities would remain beyond the end of apartheid. Describing whiteness as a theological problem that is not synonymous with apartheid as a theological problem was probably even less common (even though the building blocks for such an analysis were in place by this time).

12.Lind Alcoff's (2015) recent work attempt to chart a way between the rejection of white identity as only possible response to whiteness, on the one hand, and the fatalistic connection made between whiteness and racism, as if it is impossible to fatalistic connection made between whiteness and racism, as if it is impossible to separate the two. Given the long arm of history, we can foresee a future in which white identity remains even though white supremacy is no longer at play. That said, it is exactly in being a subjectivity and positionality problemmatically bound

13.'om weer te gaan kyk waarheen ons op pad was met die projek toe FW ons so onbeskof in die rede geval het!' 
But ending apartheid did disrupt this early attempt by white theologians to start exploring whiteness critically. The interruption was possibly inevitable, given the close connection between apartheid and whiteness. This close connection is perhaps best seen in the discourse around prophetic theology used within the project. Implied in the description above, the position assumed in descriptions of prophetic theology was that of taking on the task of convincing the middle ground to abandon their support for apartheid. In this, there was little room to explore that it might mean to be complicit in maintaining whiteness in spite of strong opposition to apartheid.

To what extent LMWC was able to critically engage whiteness is the question that underlies my analysis up to this point. Much of what was presented in these meetings decentred the importance of race and whiteness in favour of class. Yet the meetings also revealed that different challenges might be at stake, which is an important strategic observation in the ideological struggle around white supremacy. One such challenge was the task of taking the theological response to white racism that Black Theology presented seriously, in the search for an appropriate white theological response. 'Response' in this context implied taking up the challenge of Black Theology. But simultaneously there are questions around what is politically attainable, what the most immediate goals should be, and how to move the white community towards support of the concrete policies and programmes that are part of the longer process of dismantling racism.

The emphasis within LMWC was on being strategically wise, which included discerning what is attainable with a particular group of white people. This included an insistence that they should refrain from making 'outsiders' of people and that there should be sensitivity to the struggles white people had when breaking with their communities. However, these strategies are explicitly focused on the so-called 'white middle ground', not those seeking to maintain the status quo. In short, those open to change should be guided towards a deeper commitment to transformation, but those committed to maintaining the status quo should be actively opposed (Institute for Contextual Theology 1989:3-4).

At some points in LMWC, the intention for more conceptual work around liberating whiteness was indeed present, but the focus was this strategic work for changing the white middle ground, for drawing them into a greater support for democracy and transformation of society. The aim was white solidarity with the struggle of the black majority against apartheid.

With the benefit of hindsight, we might argue that a key distinction that the LMWC could not yet articulate was between a disruption of whiteness and apartheid, on the one hand, and a disruption of whiteness and middle-class living, on the other. While whiteness was evidently maintained through a racist political system in South Africa, the dismantling of apartheid in itself did not and could not dismantle whiteness on its own. Analyses in the project correctly noted that political change without economic transformation will result in the perpetuation of a system of oppression beyond the end of apartheid. But, though whiteness was indeed, and continues to be, maintained through a system of class inequality, class solidarity in and of itself does not dismantle a problematic whiteness. In analysing the project from beyond apartheid, I will therefore consciously highlight the importance of the ideological struggle emphasised in the overview above.

\section{Possible implications}

In the minutes of the September 1988 meeting, describing the opening by Michael Worsnip mentioned in the initial overview of the project, it is noted that:

The conference began with an introduction by Fr. Michael Worsnip. He explained that the purpose of the workshop was to explore strategies for liberating whites through the churches. Black consciousness and black theology inspired the notion of a theology for whites in the early 1970s but this idea did not take off. This workshop was intended thus to reopen the debate and to discuss whether the moment had come to deepen our understanding of a specific approach to white Christians. (Institute for Contextual Theology 1988b:1)

From even a cursory reading of contemporary South African discourse, it is clear that Nolan's rhetorical question (which by implication questioned the future importance of Black Consciousness) was not accurate. Today, Black Consciousness in general and Steve Biko in particular remain key sources for a contemporary public discourse on race and racism. Though the student protests of 2015 indeed went to great lengths to highlight the effects of ongoing inequality, symbolised in the call that \#feesmustfall, it was also made quite clear that the problems facing universities cannot be reduced to one of class inequalities. There are questions of curriculum, the politics of knowledge production, and, in highly personalised terms, the way in which pedagogic spaces remain racialised.

Historian Philip Bonner recently observed that the nonracialism of the ANC and Black Consciousness would probably always remain simultaneously present, even while different voices might be prominent at different times (Bonner 2014:36). Black Consciousness and anti-racism are not static but transform together with a changing white racism; yet, as these become more prominent in a particular time, Black Theology (as a liberating theology that insists on the salience of race in the oppressive structures of our time) inevitably becomes more prominent as well.

But its relevance is not to be found in its popularity alone. The challenge remains whether white Christians are able to respond to the questions that emerge when Black Theologians name race in general and whiteness in particular as key theological problems of modernity in general and modern South Africa in particular. If the 1970s attempt to work out the implications of the challenge of Black Theology for white 
Christians (see Kleinschmidt 1972) did not take off, then the same can be said of the ICT's LMWC project of the late 1980s.

But the project still remains a marker of such an attempt. Gerald West recently described this particular project as a space of explicitly focusing on whiteness and becoming conscious of whiteness (West 2012:69-70). Given the ongoing struggle around race and whiteness, Willem Saayman suggested turning back to this project as a resource for exploring what an LMWC might imply. And as mentioned in the introduction, Klippies Kritzinger has suggested that at least some aspects of the approach of white withdrawal need to be reconsidered in the present in order to do critical work on whiteness.

The challenge remains to hold race and racism as central problems that need to be explored theologically. The 1987 ICT resolution could well be repeated 30 years later: an LMWC will need to give particular attention to issues of 'fear, guilt and material interests'.

The project correctly identified that the church as a site of ideological struggle is a site of struggle concerning beliefs, prayers, and religious symbols. Yet the task of disrupting these ideological and theological structures of whiteness was not adequately engaged in, perhaps partly because it was dominated by an analysis that drew the gaze towards the sites of economic struggle on the one hand, and partly due to the building of broad alliances that, in the sites of political struggle, could contribute to the disruption of apartheid on the other. The struggle remains on the whiteness of theology.

\section{Conclusion}

This analysis does not seek to undermine the prophetic theology underpinning this project, nor the important work done in thinking through what participating in the struggle would mean for those in predominantly privileged social locations, nor to undermine the importance of thinking through questions of class under capitalism given the levels of economic inequality.

Analysing the white church as a site of ideological struggle opened up possibilities for exploring how whiteness is maintained beyond political and economic dominance, although circumstances shifted attention primarily to the sites of political and economic struggle. The 1988-1990 ICT project $A$ Liberating Ministry to the White Community provides a moment in which the particular theological work required from white Christians in a racist society was explored, even though the end of apartheid also brought an end to the work of disrupting whiteness.

Given the re-emerging emphasis on racism and whiteness in South Africa, the project can serve as a starting point to consciously explore how the church, as an ideological site, maintains whiteness through the faiths, beliefs, and symbols of Christianity. But the project can also spur an examination of how the faiths, beliefs, and symbols of Christianity can work for the disruption of whiteness.

\section{Acknowledgements Competing interests}

The author declares that he has no financial or personal relationships which may have inappropriately influenced him in writing this article.

\section{References}

Ackerman, D.M., 1988, Letter, Denise Ackerman to Fiona Bulman, Unpublished document, personal archives.

Alcoff, L.M., 2015, The future of whiteness, Polity Press, Cambridge.

Anderson, P., 1976, 'The Antimonies of Antionio Gramsci', New Left Review 100, 5-78.

Bonner, P., 2014, 'The antinomies of Nelson Mandela', in R. Barnard (ed.), The Cambridge Companion to Nelson Mandela, pp. 29-49, Cambridge University Press, New York.

Bulman, F., 1989, Letter, Fiona Bulman, 25 September 1989, Unpublished document, personal archives.

Institute for Contextual Theology, 1987, Notes of white contextual theology discussion 15-09-87 Unisa, Unpublished document, personal archives.

Institute for Contextual Theology, 1988a, Position paper: A librating ministry to the white community, Unpublished document, personal archives.

Institute for Contextual Theology, 1988b, Minutes of the ICT workshop : 'A liberating ministry to whites' held at the Edendale Lay Centre from 23-25 September 1988, Unpublished document, personal archives.

Institute for Contextual Theology, 1988c, Project Proposal: Ministry for White Liberation, Unpublished document, personal archives.

Institute for Contextual Theology, 1988d, A Liberating Ministry to the White Community, Unpublished document, personal archives.

Institute for Contextual Theology, 1988e, Minutes of central committee for A Liberating Ministry to the White Community, 10 December 1988, Unpublished document, personal archives.

Institute for Contextual Theology, c 1989, Strategy and Tactics, Unpublished document, personal archives.

Institute for Contextual Theology, 1989a, Report on ICT Workshop: The White Christian community as a site of struggle, 2-4 June 1989, LUMKO, Unpublished document, personal archives.

Institute for Contextual Theology, 1989b, Agenda and minutes of Ministry to Whites Conference Planning Committee Meeting, 26 August 11:00, Unpublished document, personal archives.

Institute for Contextual Theology, 1989c, Negotiations, Defiance and the Church, Institute for Contextual Theology, Braamfontein.

Kleinschmidt, H., 1972, White Liberation: A SPRO-CAS two publication, Raven Press, Braamfontein

Kritzinger, J.N.J., 1988, 'Black Theology: a challenge to mission', PhD thesis, University of South Africa.

Kritzinger, J.N.J., c 1989, Letter, Klippies Kritzinger to Sipho Tshelane, Unpublished document, personal archives.

Kritzinger, J.N.J. (ed.), 2004, Exploring theology: An introductory dictionary, Research Institute for Theology and Religion - University of South Africa, Pretoria.

Kritzinger, J.N.J., 2013, 'The Struggle for justice in South Africa (1986-1990): The participation of the Dutch Reformed Mission Church and the Dutch Reformed Church in Africa', in M. Plaatjie Van-Huffel \& R. Vosloo (eds.), Reformed Churches in South Africa and the Struggle for Justice: Remembering 1960-1990, pp. 92-117, SUN Press, Stellenbosch.

Kritzinger, J.N.J., 2015, Transformative Encounters towards Life: Taking up the legacy of David. J. Bosch, David Bosch memorial lecture delivered at the Southern African Missiological Society on 12 March 2015, Unpublished document, personal archives.

Lamola, J. M., 1988, Letter, Lamola to Kritzinger, 29 January 1988, Unpublished document, personal archives.

Langeveldt, C., 1989, The Church as a site of struggle, Unpublished document, personal archives.

Mabuza, W. M., 2009, 'Kairos Revisited: investigating the relevance of The Kairos Document for church-state relations within a democratic South Africa', PhD thesis, University of Pretoria, Pretoria.

Mothlabi, M., 1987, “'Kairos” revisited: it's social ethical implications', in J.W. Hofmeyr, J.H.H. du Toit \& C.J.J. Froneman (eds.), Perspektiewe op/perspectives on Kairos, pp. 89-101, Lux Verbi, Cape Town.

Nolan, A., 1988, God in South Africa, David Philip, Cape Town.

Nolan, A., 1989, The Three Skills, Unpublished document, personal archives. 
Saayman, W., 1991, Christian MIssion in South Africa, University of South Africa, Pretoria.

Steyn, M., 2005 “"White talk": white South Africans and the management of diasporic whiteness', in A.J. Lopez (ed.), Postcolonial Whiteness: A Critical Reader on Race and Empire, pp. 119-135, State University of New York Press, New York.

Vosloo, R., 2013, 'Remembering the role of the Reformed Churches in the struggle for justice in South Africa (1960-1990): Some remarks on the promise and pitfalls of memory and historiography', in M. Plaatjie Van-Huffel \& R. Vosloo (eds.),
Reformed Churches in South Africa and the struggle for Justice: Remembering 1960-1990, pp. 15-25, SUN Press, Stellenbosch.

West, G., 2012, 'White Theology in a Black Frame: Betraying the Logic of Social Location', in J.R. Cochrane, E.K. Bongmba, I.A. Phiri, D. van der Water (eds.), Living on the Edge: Essays in Honour of Steve de Gruchy, Activist and Theologian, pp. 60-78, Cluster Publications, Dorpspruit.

West, G., 2014, Liberation Hermeneutics after Liberation in South Africa, Studies in World Christianity and Interreligious Relations 48, 341-381. 